\title{
Development of the lesser grain borer (Rhyzopertha dominica F.) on malt barley and fodder barley grain
}

\author{
Rozwój kapturnika zbożowca (Rhyzopertha dominica F.) \\ na ziarnie jęczmienia browarnego i pastewnego
}

\author{
Mariusz Nietupski, Emilia Bujak, Bożena Kordan
}

\begin{abstract}
Summary
A study was carried out to determine the effect of barley grain used for different purposes (malt or fodder production) on the development of the lesser grain borer (Rhyzopertha dominica F.). The development of the pest insect was investigated on the grain of barley cultivars belonged to two different utilization types. The grain from cultivars used in the brewery industry (Presige, Sebastian, Żeglarz, Stratus, Philadelphia, Blask, Mauritia, Bolina and Class) and from fodder cultivars (Frontier, Orthega, Antek, Justina, Widawa, Tocada). The results revealed that both fodder and malt barley grain provided a suitable habitat for the development of the lesser grain borer. Differences in the number of offspring growing on the grain of either types of barley cultivars proved to be non-significant. However, it was shown that the lesser grain borer produced much more dust and caused larger grain mass loss when foraging on malt cultivars. Among the malt cultivars, cultivar Mauritia was the most resistant one to foraging by $R$. dominica. Out of the fodder cultivars, grain produced by the cultivar Tocada was the least damaged. There was a positive correlation between the number of the lesser grain borer's offspring imagines and the mass of dust as well as loss of grain mass. It was found that an increase in the number of imagines was more strongly correlated with the grain mass loss than with the mass of produced dust.
\end{abstract}

Key words: leeser grain borer, stored barley, storage pests

\section{Streszczenie}

W przeprowadzonych badaniach podjęto próbę uzyskania odpowiedzi, czy ziarno jęczmienia o różnym typie użytkowym (odmiany browarne i pastewne) jest siedliskiem różnicującym rozwój kapturnika zbożowca (Rhyzopertha dominica F.). Badano rozwój szkodnika na ziarnie jęczmienia należącym do dwóch różnych typów użytkowych. Ocenie poddano ziarno odmian przeznaczonych do wykorzystania w przemyśle browarnym (Prestige, Sebastian, Żeglarz, Stratus, Philadelphia, Blask, Mauritia, Bolina, Class) oraz odmiany pastewne (Frontier, Orthega, Antek, Justina, Widawa, Tocada). Uzyskane wyniki wskazują, że ziarno jęczmienia browarnego i pastewnego jest dobrym siedliskiem dla rozwoju kapturnika zbożowca. Różnice w liczebności pokolenia potomnego, rozwijającego się na ziarnie badanych typów użytkowych jęczmienia, okazały się nieistotne. Stwierdzono jednak, że szkodnik wytworzył większą masę pyłu i spowodował większy ubytek masy ziarna żerując na odmianach browarnych. Najbardziej odporną odmianą na żerowanie $R$. dominica, wśród odmian browarnych, okazała się odmiana Mauritia. W grupie odmian pastewnych było to ziarno odmiany Tocada. Między liczebnością imagines pokolenia potomnego badanego chrząszcza a masą pyłu i ubytkiem masy ziarna istnieje dodatnia korelacja. Stwierdzono, że wzrost liczebności imagines był silniej skorelowany z ubytkiem masy ziarna niż z masą powstałego pyłu.

Słowa kluczowe: kapturnik zbożowiec, przechowywany jęczmień, szkodniki magazynowe

\footnotetext{
Uniwersytet Warmińsko-Mazurski w Olsztynie

Katedra Fitopatologii i Entomologii

Prawocheńskiego 17, 10-722 Olsztyn

mariusz.nietupski@uwm.edu.pl
} 


\section{Wstęp / Introduction}

Kapturnik zbożowiec, Rhyzopertha dominica F. (Coleoptera: Bostrichidae) to gatunek szeroko rozprzestrzeniony $\mathrm{w}$ strefie klimatu tropikalnego i subtropikalnego, pochodzący prawdopodobnie $\mathrm{z}$ rejonów Indii, Indochin i południowych Chin (Jia i wsp. 2008). W Polsce gatunek ten obserwowano dosyć licznie już w połowie 20. wieku w magazynach $\mathrm{z}$ importowanym zbożem (Śliwiński 1957). Obecnie uznawany jest za jednego z groźniejszych szkodników pierwotnych ziarna zbóż, często występujący w magazynach i przechowalniach. Najodpowiedniejszym pokarmem dla jego rozwoju są całe i uszkodzone ziarniaki zbóż, ryż, kukurydza, kasze, płatki, natomiast rozwój na produktach bardzo sypkich jest powolny lub niemożliwy (Kordan i wsp. 2005; Kłyś 2006; Mebarkia i wsp. 2009; Edde 2012).

Znaczenie kapturnika zbożowca jako szkodnika przechowywanej żywności w naszym kraju może wzrastać w kolejnych latach. Wynikać to może m.in. z faktu: zdolności do lotu, a tym samym migracji osobników dorosłych, które mogą przemieszczać się w okresie letnim między magazynami (Toews i wsp. 2006; Klejdysz i Nawrot 2010); relatywnie niskich temperatur minimalnych $\left(17-18^{\circ} \mathrm{C}, 55 \%\right.$ w.w.p. - wilgotność względna powietrza) potrzebnych do rozwoju chrząszczy (Gołębiowska 1962; Longstaff 1999) oraz pojawiania się odporności na związki chemiczne stosowane do jego zwalczania w magazynach (deltametryna, fosforowodór) (Lorini i Halley 1999; Edde 2012). Duże straty w masie i jakości magazynowanych produktów, będące skutkiem żerowania tego gatunku, wskazują na konieczność prowadzenia badań, w których poznawany jest behawior i preferencje pokarmowe tego szkodnika (Jood i wsp. 1996; Nawrot 2002; Park i wsp. 2008).

W przeprowadzonych badaniach podjęto próbę uzyskania odpowiedzi, czy ziarno jęczmienia o różnym typie użytkowania (odmiany browarne i pastewne) jest siedliskiem różnicującym rozwój badanego gatunku chrząszcza.

\section{Materiały i metody / Materials and methods}

W przeprowadzonym doświadczeniu badano rozwój kapturnika zbożowca na ziarnie jęczmienia należącym do dwóch różnych typów użytkowych. Ocenie poddano ziarno odmian przeznaczonych do wykorzystania w przemyśle browarnym (Prestige, Sebastian, Żeglarz, Stratus, Philadelphia, Blask, Mauritia, Bolina, Class) oraz odmiany pastewne (Frontier, Orthega, Antek, Justina, Widawa, Tocada). Próbki przeznaczone do badań pochodziły ze Stacji Doświadczalnej Oceny Odmian Centralnego Ośrodka Badania Odmian Roślin Uprawnych we Wrócikowie koło Olsztyna. Badane ziarno kondycjonowano w komorze hodowlanej $\left(30^{\circ} \mathrm{C}, 70 \%\right.$ w.w.p.) przez 7 dni. Po tym czasie badany materiał przesiewano przez sito o oczkach $1 \mathrm{~mm}$, celem odsiania pyłu, a następnie odważano $30 \mathrm{~g}$ próbki. Ziarno badanych odmian umieszczano w winidurowych pojemnikach o średnicy $8 \mathrm{~cm}$ i wysokości $3 \mathrm{~cm} \mathrm{z}$ otworem wentylacyjnym w wieczku, który zabezpieczono szyfonową siatką uniemożliwiającą wydostanie się chrząszczy.
Na próbki ziarna nanoszono 20 osobników badanego gatunku chrząszcza, a następnie monitorowano ich rozwój w stałych warunkach temperatury $\left(30^{\circ} \mathrm{C}\right)$ i wilgotności (70\% w.w.p.) w komorze hodowlanej firmy Sanyo MLR $350 \mathrm{H}$. W doświadczeniu używano osobników 1-2 dniowych, bez rozdziału płci, które po wylęgu w hodowli masowej przenoszono do kombinacji kontrolnych. Naniesione chrząszcze rozwijały się przez 3 tygodnie, a następnie usuwano je z pojemników. Po 7 tygodniach zliczono żywe i martwe osobniki dorosłe ustalając liczebność populacji potomnej szkodnika. Ziarno ważono w celu stwierdzenia straty masy jęczmienia, zważono też pył, który pozostał po żerowaniu szkodnika. Chrząszcze kapturnika zbożowca użyte w doświadczeniu pochodziły z hodowli masowej szkodnika, prowadzonej w Katedrze Fitopatologii i Entomologii Uniwersytetu Warmińsko-Mazurskiego w Olsztynie. Doświadczenie przeprowadzono w 5 powtórzeniach.

Istotność różnic między średnimi, testowano za pomocą analizy wariancji (ANOVA), przyjmując ich istotność statystyczną dla $\mathrm{p} \leq 0,05$. Obliczenia przeprowadzono na danych rzeczywistych. Uzyskane średnie zestawiono w grupy jednorodne przy zastosowaniu testu istotności Duncana. Każdą grupę jednorodną, grupującą średnie nieróżniące się statystycznie między sobą, oznaczono identycznym indeksem literowym: a, b, c, itp. Obliczono również dla średnich opisujących wartości badanych parametrów rozwojowych $R$. dominica błąd standardowy średniej (SEM), którego wartość zaznaczono graficznie na wykresach prezentujących dane. W celu stwierdzenia zależności występujących między wybranymi zmiennymi wykonano analizę korelacji liniowej Pearsona.

\section{Wyniki i dyskusja / Results and discussion}

Ziarno zbóż należy do grupy produktów, na których dobre warunki do rozwoju znajduje kapturnik zbożowiec (Bashir 2002; Kordan i wsp. 2005; Edde 2012). Stwierdzono ponadto, że ziarniaki różnych odmian mogą różnić się między sobą np. zawartością białka $(\mathrm{N} * 5,7)$ oraz jego poszczególnych frakcji, co może pozostawać w bezpośrednim związku z rozwojem szkodników magazynowych (Nietupski i wsp. 2006; Konopka i wsp. 2007).

W przeprowadzonych badaniach ziarno dwóch typów użytkowych jęczmienia okazało się podobnym, co do jakości, siedliskiem do rozwoju $R$. dominica. Więcej osobników potomnych (chrząszczy) stwierdzono na ziarnie odmian pastewnych (średnio 93,0 szt.) niż browarnych (średnio 88,1 szt.), jednak różnice nie były istotne (ANOVA) (tab. 1). Stwierdzono natomiast, że stadia rozwojowe badanego gatunku chrząszcza wytworzyły istotnie większe ilości pyłu (średnio 3,15 g), a ich żerowanie spowodowało większy ubytek masy ziarna (średnio 4,60 g) w czasie rozwoju na odmianach browarnych. W badaniach ocenie poddano również podatność ziarna odmian browarnych i pastewnych na żerowanie kapturnika zbożowca. Spośród odmian browarnych najwyższą odpornością, opisaną przez najmniejszą liczebność pokolenia potomnego chrząszczy, charakteryzowało się 6 odmian (Mauritia, Stratus, Blask, Class, Prestige i Bolina), zakwalifikowanych przez test Duncana 


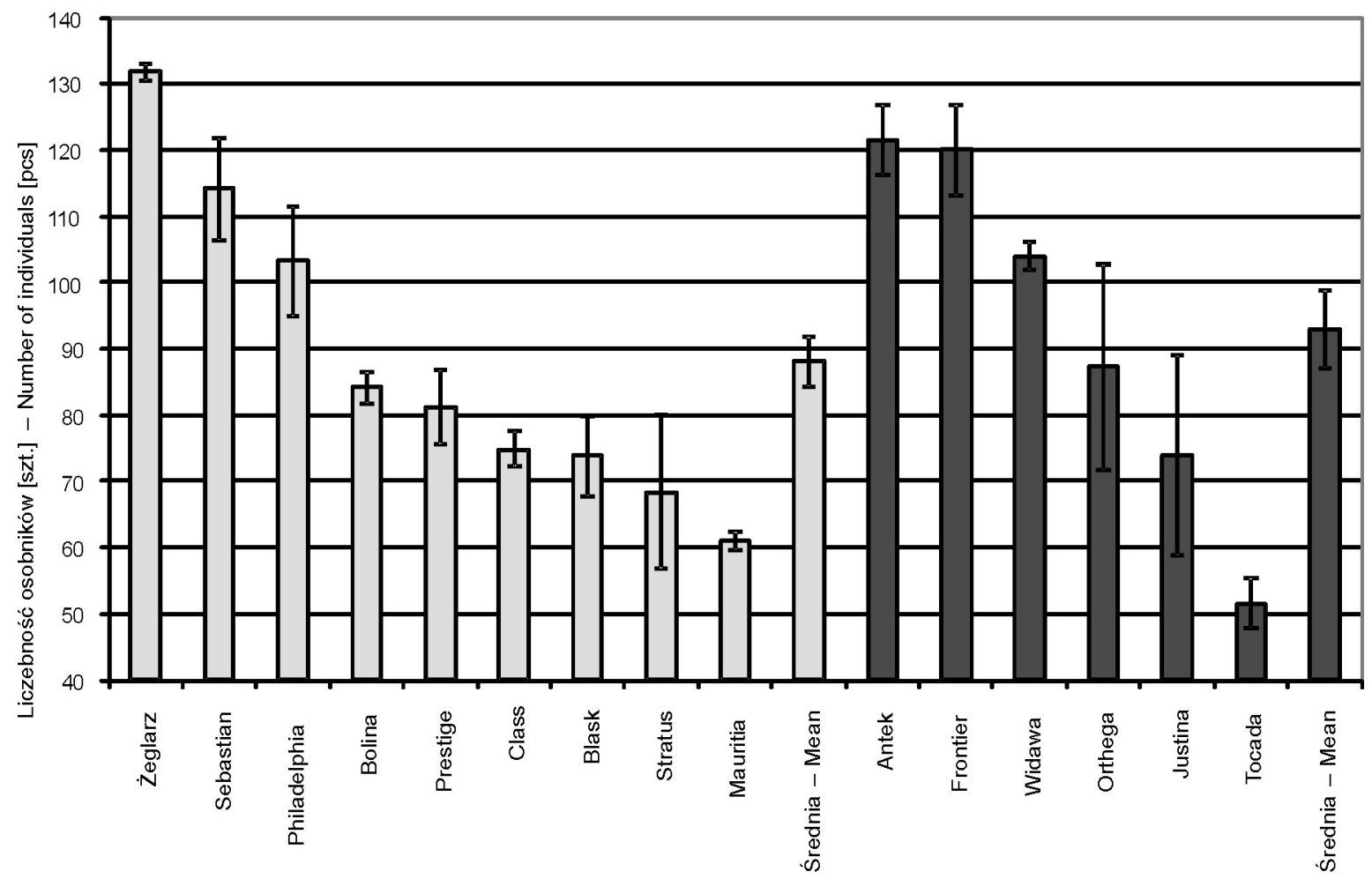

Odmiana - Cultivar

Rys. 1. Liczebność chrząszczy pokolenia potomnego $R$. dominica rozwijającego się na ziarnie badanych odmian jęczmienia Fig. 1. Number of $R$. dominica offspring beetles developing on grain of analyzed barley cultivars

*a, b, c - grupy jednorodne - homogenous groups

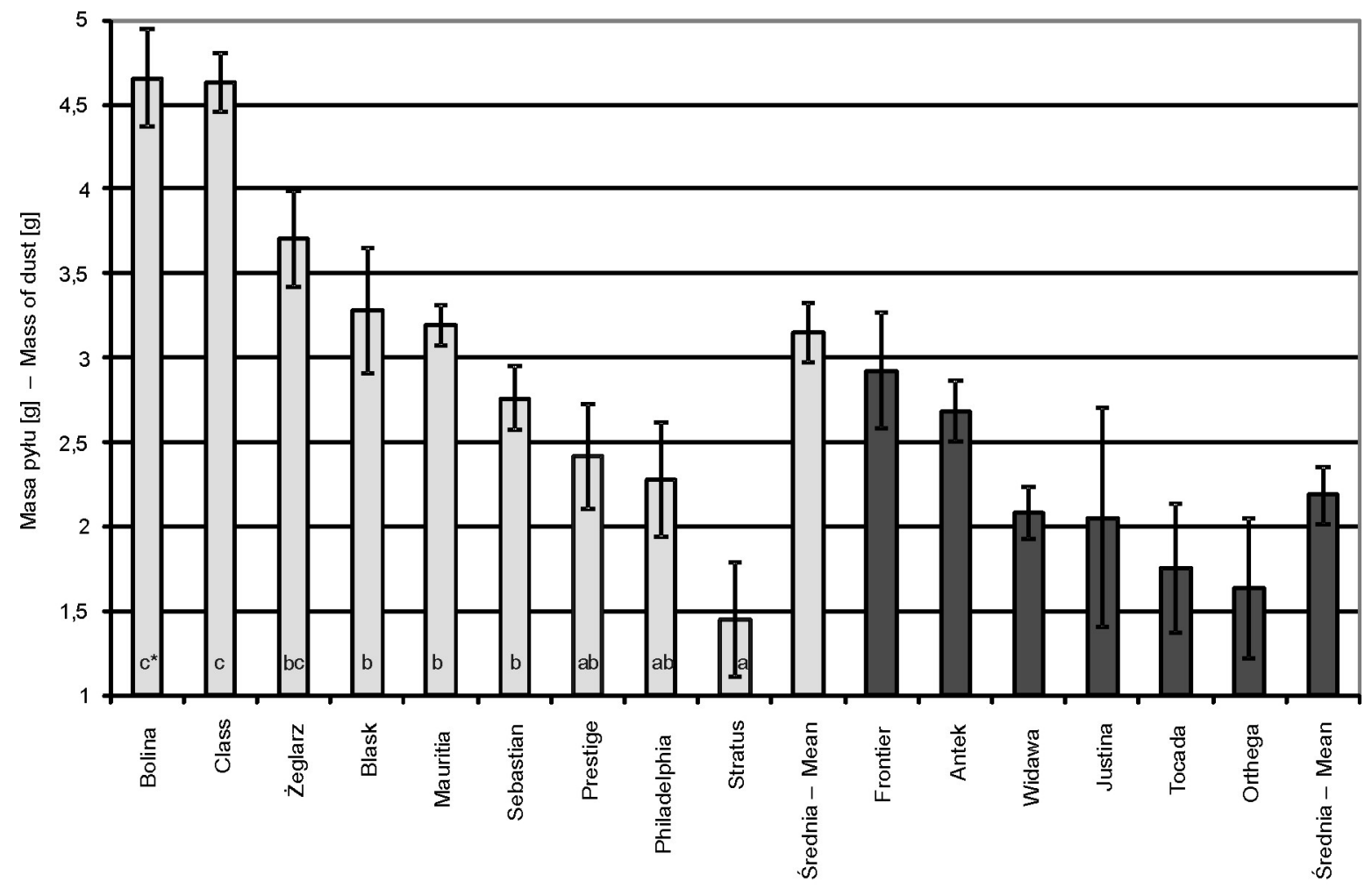

Odmiana - Cultivar

Rys. 2. Masa pyłu wytworzonego przez żerujące osobniki $R$. dominica

Fig. 2. Mass of dust produced by foraging $R$. dominica individuals

*a, b, c - grupy jednorodne - homogenous groups 


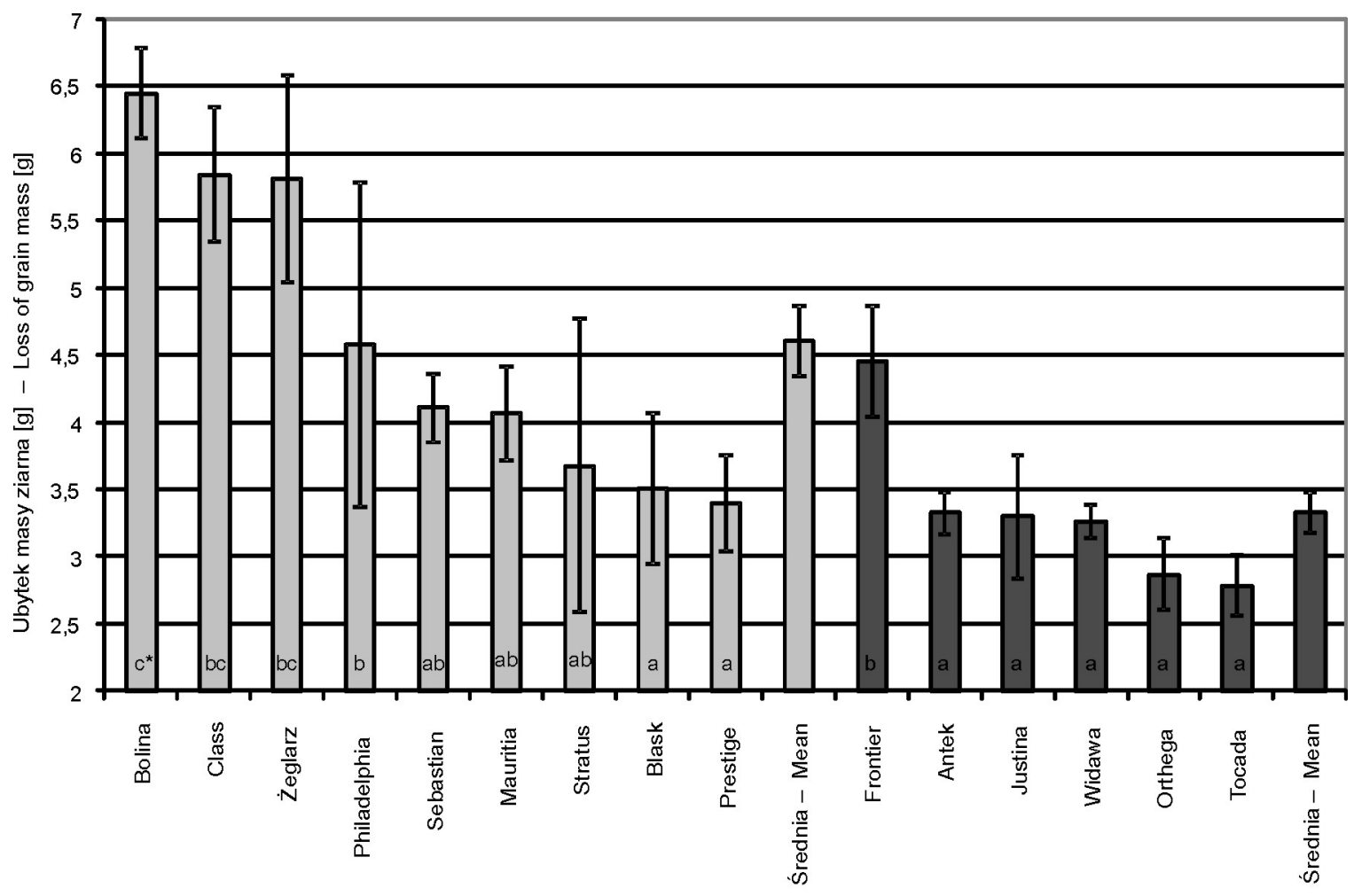

Rys. 3. Ubytek masy ziarna powstały na skutek żerowania $R$. dominica

Odmiana - Cultivar

Fig. 3. Loss of grain mass caused by foraging $R$. dominica

*a, b, c - grupy jednorodne - homogenous groups

do tej samej grupy jednorodnej. Wśród nich najmniejszą liczebność imagines pokolenia potomnego stwierdzono na kombinacji z ziarnem odmiany Mauritia - średnio 61,0 osobników $R$. dominica. Z grupy odmian pastewnych najmniejszą odpornością na żerowanie badanego gatunku chrząszcza charakteryzowało się ziarno odmiany Sebastian (średnio 114,2 osobników) i Żeglarz (średnio 131,8 osobników) (rys. 1). W przypadku wołka zbożowego (Sitophilus granarius L.) duże ilości pyłu powstałego w czasie żerowania są skorelowane $\mathrm{z}$ dobrą jakością pokarmu (Niewiada i wsp. 2003). Specyfika rozwoju kapturnika zbożowca wymusza wytwarzanie, przez postacie dorosłe, dużych ilości pyłu, w którym rozwijać się mogą młode stadia larwalne tego gatunku (Nawrot 2002). Masa pyłu może być zmniejszana zatem na skutek intensywnego żerowania larw. Kombinacjami $\mathrm{z}$ grupy odmian browarnych, w których $R$. dominica wytworzył największe ilości pyłu, było ziarno odmian Bolina (średnio 4,66 g) i Class (średnio 4,63 g) (rys. 2). Bardzo małą masę pyłu stwierdzono natomiast na ziarnie odmiany Stratus (średnio 1,45 g). Wśród odmian pastewnych największe ilości pyłu stwierdzono na ziarnie odmiany Frontier (średnio 2,92 g) i Antek (średnio 2,69 g), najmniejsze na odmianie Orthega (średnio 1,63 g), jednak różnice między odmianami nie były istotne (tab. 1). Analiza ubytku masy ziarna, powstałego na skutek żerowania stadiów kapturnika zbożowca ujawniła, że największy ubytek odnotowano na ziarnie odmian Bolina (średnio 6,45 g), Class (średnio 5,84 g) i Żeglarz (średnio 5,82 g), najmniejszy na kombinacjach z ziarnem odmian Blask (średnio 3,51 g) i Prestige (średnio 3,40 g) (rys. 3). W grupie odmian pastewnych ubytek masy kształtował się na podobnym poziomie wśród 5 odmian, a istotnie wyższe jego wartości stwierdzono na kombinacji z ziarnem odmiany Frontier (średnio 4,45 g).

Związek między masą pyłu wytwarzanego przez żerujące osobniki $R$. dominica a atrakcyjnością pokarmu w przypadku tego gatunku może być nie do końca jednoznaczny. Masa pyłu może być zmniejszana przez żerujące, młode larwy kapturnika. Bardziej wiarygodnym wskaźnikiem jakości pokarmu w tym przypadku, oprócz parametrów demograficznych, może być ubytek masy ziarna. W celu stwierdzenia związku między podatnością ziarna badanych odmian jęczmienia (rozumianą jako

Tabela 1. Istotność czynnika odmianowego w doświadczeniu badającym rozwój $R$. dominica na ziarnie jęczmienia

Table 1. Significance of cultivar factor on the development of $R$. dominica on barley grain

\begin{tabular}{l|c|c|c}
\hline \multirow{1}{*}{$\begin{array}{c}\text { Kombinacja } \\
\text { Combination }\end{array}$} & \multicolumn{3}{|c}{ Badany parametr - Parameter testing } \\
\cline { 2 - 4 } & $\begin{array}{c}\text { imagines } \\
\text { adults }\end{array}$ & $\begin{array}{c}\text { pył } \\
\text { dust }\end{array}$ & $\begin{array}{c}\text { ubytek masy ziarna } \\
\text { grain mass loss }\end{array}$ \\
\hline $\begin{array}{l}\text { Odmiany browarne } \\
\text { Malt cultivars } \\
\mathrm{n}=9\end{array}$ & $\mathrm{p}<0,01$ & $\mathrm{p}<0,01$ & $\mathrm{p}<0,05$ \\
\hline $\begin{array}{l}\text { Odmiany pastewne } \\
\text { Fodder cultivars } \\
\mathrm{n}=6\end{array}$ & $\mathrm{p}<0,01$ & r.n. & $\mathrm{p}<0,01$ \\
\hline $\begin{array}{l}\text { Browarne x pastewne } \\
\text { Malt } \mathrm{x} \text { fodder cultivars }\end{array}$ & r.n. & $\mathrm{p}=0,05$ & $\mathrm{p}<0,05$ \\
\hline
\end{tabular}

r.n. - różnice nieistotne - not significant differences 
Tabela 2. Wartości współczynnika korelacji $r$ dla badanych parametrów opisujących rozwój $R$. dominica

Table 2. Values of the $r$ correlation coefficient for analyzed parameters describing the development of $R$. dominica

\begin{tabular}{l|c|c|c}
\hline \multirow{2}{*}{$\begin{array}{c}\text { Badany } \\
\text { parametr } \\
\text { Parameter } \\
\text { testing }\end{array}$} & \multicolumn{3}{|c}{$\begin{array}{c}\text { Liczebność chrząszczy pokolenia potomnego } \\
\text { Number of offspring beetles }\end{array}$} \\
\cline { 2 - 4 } $\begin{array}{c}\text { odmiany browarne } \\
\text { malting cultivars }\end{array}$ & $\begin{array}{c}\text { odmiany pastewne } \\
\text { fodder cultivars }\end{array}$ & $\begin{array}{c}\text { razem } \\
\text { total }\end{array}$ \\
\hline $\begin{array}{l}\text { Masa pyłu } \\
\text { Mass of dust }\end{array}$ & 0,06 & 0,80 & 0,15 \\
\hline $\begin{array}{l}\text { Ubytek masy } \\
\text { Grain } \\
\text { mass loss }\end{array}$ & 0,34 & 0,68 & 0,27 \\
\hline
\end{tabular}

liczebność chrząszczy pokolenia potomnego) a masą pyłu i ubytkiem masy ziarna, powstałych na skutek żerowania $R$. dominica, wyznaczono wartość współczynnika korelacji $r$ (tab. 2). Jego analiza ujawnia, że między liczebnością imagines pokolenia potomnego badanego chrząszcza a masą pyłu i ubytkiem masy ziarna istnieje dodatnia korelacja. Stwierdzono, że wzrost liczebności imagines potomnych był silniej skorelowany $(r=0,27) \mathrm{z}$ ubytkiem masy ziarna, niż $\mathrm{z}$ masą powstałego pyłu $(r=0,15)$. Bardzo silną korelację, między badanymi parametrami, stwierdzono natomiast dla analizy, w której wzięto pod uwagę tylko kombinacje z ziarnem odmian pastewnych.

\section{Wnioski / Conclusions}

1. Ziarno jęczmienia browarnego i pastewnego jest dobrym siedliskiem dla rozwoju kapturnika zbożowca. Różnice w liczebności imagines pokolenia potomnego, rozwijającego się na ziarnie badanych typów użytkowych jęczmienia okazały się nieistotne. Stwierdzono jednak, że szkodnik wytworzył większą masę pyłu i spowodował większy ubytek masy ziarna żerując na odmianach browarnych.

2. Najbardziej odporną na żerowanie $R$. dominica, wśród odmian browarnych, okazała się odmiana Mauritia. $\mathrm{W}$ grupie odmian pastewnych było to natomiast ziarno odmiany Tocada.

3. Między liczebnością imagines pokolenia potomnego badanego chrząszcza a masą pyłu i ubytkiem masy ziarna istnieje dodatnia korelacja. Stwierdzono, że wzrost liczebności imagines był silniej skorelowany $\mathrm{z}$ ubytkiem masy ziarna niż z masą powstałego pyłu.

\section{Literatura / References}

Bashir T. 2002. Reproduction of Rhyzopertha dominica (F.) (Coleoptera: Bostrichidae) on different host-grains. Pakistan J. Biol. Sci. 5 (1): 91-93.

Edde P.A. 2012. A review of the biology and control of Rhyzopertha dominica (F.) the lesser grain borer. J. Stored Prod. Res. $48: 1-18$.

Gołębiowska Z. 1962. Przyczynek do badań nad ekologią kapturnika zbożowca - Rhizopertha dominica F. (Col., Bostrichidae). Pol. Pismo Ent. 1-2: 39-51.

Jia F., Toews M.D., Campbell J.F., Ramaswamy S.B. 2008. Survival and reproduction of lesser grain borer, Rhyzopertha dominica (F.) (Coleoptera: Bostrichidae) on flora associated with native habitats in Kansas. J. Stored Prod. Res. 44: 366-372.

Jood S., Kapoor A.C., Singh R. 1996. Effect of insect infestation and storage on lipids of cereal grains. J. Agric. Food Chem. 44 (6): $1502-1506$.

Klejdysz T., Nawrot J. 2010. First record of outdoor occurrence of stored-product coleopterans in arable landscape in Poland. J. Plant Prot. Res. 50 (4): 551-553.

Kłyś M. 2006. Nutritional preferences of the lesser grain borer Rhizopertha dominica F. (Coleoptera, Bostrichidae) under conditions of free choice of food. J. Plant Prot. Res. 46 (4): 359-367.

Konopka I., Fornal Ł., Dziuba M., Czaplicki S., Nałęcz D. 2007. Composition of proteins in wheat grain streams obtained by sieve classification. J. Sci. Food Agric. 87: 2198-2206.

Kordan B., Ciepielewska D., Nietupski M. 2005. Wpływ wybranych odmian zbóż na rozwój kapturnika zbożowca (Rhizopertha dominica F.). Prog. Plant Prot./Post. Ochr. Roślin 45 (2): 794-796.

Longstaff B.C. 1999. An experimental and modelling study of the demographic performance of Rhyzopertha dominica (F.). I. Development rate. J. Stored Prod. Res. 35: 89-98.

Lorini I., Halley D.J. 1999. Deltamethrin resistance in Rhyzopertha dominica (F.) (Coleoptera: Bostrichidae), a pest of stored grain in Brazil. J. Stored Prod. Res. 35: 37-45.

Mebarkia A., Guechi A., Mekhalif S., Makhlouf M. 2009. Biochemical composition effect of the some cereal species' on the behaviour of Sitophilus granarius L. and Rhyzopertha dominica F. species in semi-arid zone of Setif, Algeria. J. Agron. 8 (2): 60-66.

Nawrot J. 2002. Owady - Szkodniki Magazynowe. Themar, Warszawa, 149 ss.

Nietupski M., Ciepielewska D., Fornal Ł. 2006. Wpływ zróżnicowania chemicznego białek w ziarnie wybranych odmian pszenicy na rozwój szkodników magazynowych. Prog. Plant Prot./Post. Ochr. Roślin 46 (2): 420-423.

Niewiada A., Nawrot J., Klockiewicz-Kamińska E. 2003. Wpływ właściwości fizykochemicznych ziarna pszenicy różnych odmian na proces składania jaj przez samice wołka zbożowego (Sitophilus granarius L.). Prog. Plant Prot./Post. Ochr. Roślin 43 (2): $836-839$.

Park S., Arthur F.H., Bean S.R., Schober T.J. 2008. Impact of differing population levels of Rhyzopertha dominica (F.) on milling and physicochemical properties of sorghum kernel and flour. J. Stored Prod. Res. 44: 322-327.

Śliwiński Z. 1957. Rhyzopertha dominica (F.) (Coleoptera, Bostrichidae) w Polsce. Pol. Pismo Entomol. 27: 71-73.

Toews M.D., Campbell J.F., Artur F.H., Ramaswamy S.B. 2006. Outdoor flight activity and immigration of Rhyzopertha dominica into seed wheat warehouses. Entomol. Exp. Appl. 121: 73-85. 